Journal Wetenskap Health

\title{
Iodometric and Iodimetric Titration Methods
}

\author{
Benson Meyiwa \\ Faculty of Health Sciences, University of Pretoria, South Africa
}

\begin{abstract}
The discussion of this paper is to knowing and understanding the standard solution using the idometric and iodimetric titration methods. Experiment intent is to knowing and understanding the standard solution using the idometric and iodimetric titration methods. Therefore, the experiment purpose is to determine the levels of vitamin $\mathrm{C}$ based on the oxidation-reduction reaction using the iodimetric method, to determine the levels of CuSO4 based on oxidation-reduction reactions using the iodometric method and understanding the standard solution using the idometric and iodimetric titration methods.
\end{abstract}

Keywords: Iodometric, Titration, Experiment

\section{Introduction}

The term oxidation refers to any chemical change in which there is an increase in oxidation number, whereas reduction is used for every decrease in oxidation number accompanied by a loss of electrons while reduction gains an electron. Oxidizing agents are compounds in which the atoms contained have decreased their oxidation number. In contrast to reducing agents, the atoms contained have an increase in their oxidation number. The oxidation-reduction must always take place together and compensate each other. The term oxidizing reducing agent refers to a compound, not to its atom alone (Waples, 2013)

The oxidizing agent is less often determined than the reducing agent. However, the oxidizer can be determined by the reducing agent. The common reducing agents used for oxidizing determination are potassium iodide, titanium (III) ions, iron (II) ions and vanadium (II) ions. The method of redox titration using iodine solution as a pentiter is called iodometry (Merino et al. 2016).

In the analaitic process, iodine is used as an oxidation reagent (iodimetry) and iodide ion is used as a reducing reagent (iodometry). Relatively some substances are strong enough reducing reagents to be titrated directly with iodine, so the amount of iodimetric determination is small. However, there are many uses of iodometric processes. An excess of iodide ion is added to the oxidation reactant specified. With the release of iodine, which is then titrated with sodium thiosulfate solution. According to Yeboah (2013, the reaction between iodine and thiosulfate is complete. Iodine is only slightly soluble in water (0.01134) moles per liter, but slightly soluble in solutions containing iodide ions, a standard solution of iodine can be prepared by direct weighing of pure iodine and dilution in volumetric, iodine is purified by sublimation and added to a concentrated solution which was weighed carefully before and after the addition of iodine. However, when the solution is standardized against a primary standard, As 203 is the most commonly used (Suma et al. 2010)

\section{Experiment}

\section{Iodimetric Method}

Determination of vitamin $\mathrm{C}$ levels by iodometry using the iodimetric method based on the oxidation-reduction reaction between the sample as an oxidizer in an acidic atmosphere 
using the starch solution indicator with the end point of the titration marked by a change in the color of the solution from clear to pale blue (Ismail et al. 2014)

\section{Iodometric Method}

Volumetric content determination using the iodometric method is based on oxidationreduction reactions where the oxidizing sample is reduced first with $\mathrm{KI}$, then the amount of I2 released is determined by titration using the $\mathrm{Na} 2 \mathrm{~S} 2 \mathrm{O} 4$ standard solution (Oromi, 2010)

\section{Material Description}

a. Ascorbic Acid (Dirjen POM. 1979: 47)

Official name

: ACIDUM ASCORBICUM

Other names

: Ascorbic acid

Molecular formula

: $\mathrm{C} 6 \mathrm{H} 8 \mathrm{O} 6$

Molecular weight $\quad: 176.13$

Build Formulas

Description

: powder or crystal, white or slightly yellow, odorless, sour taste. By the influence of light gradually darkened. In a quiet state, in solution quickly oxidizes.

Solubility

: Easily soluble in water, rather difficult to dissolve in ethanol (95\%) $\mathrm{P}$,

Storage practically insoluble in chloroform $\mathrm{P}$, in $\mathrm{P}$ ether, and in benzene $\mathrm{P}$.

Use: as a sample

b. Acetic acid

Official name

: ACIDUM ACETICUM

Other names

: Acetic acid, vinegar

Molecular formula

: $\mathrm{CH} 3 \mathrm{COOH}$

Description

: clear, colorless, offensive odor, sour taste, sharp.

Storage

: in tightly closed container.

Use: as a reagent.

c. Sulfuric Acid (Durjen POM. 1979: 58)

Official name

: ACIDUM SULFURICUM

Other names : : sulfuric acid

Molecular formula : $\mathrm{H} 2 \mathrm{SO} 4$

Molecular weight $\quad: 98.07$

Description

: a viscous liquid such as oil, corrosive, colorless, when added to water causes heat.

Solubility

: soluble in water, ethanol (95\%) P.

Storage

: in tightly closed container.

Use: As a catalyst

Tools and Materials

Copyright (C) 2020, Journal Wetenskap Health, Under the license CC BY-SA 4.0 


\section{Tool}

The tools used are burette, stirring rod, spray bottle, erlenmeyer, measuring cup, $\mathrm{pH}$ paper, dropper pipette, and statif.

\section{Material}

The materials used were aquadest, ascorbic acid, sulfuric acid, starch indicator, I2, CuSO4. $5 \mathrm{H} 2 \mathrm{O}$, isoniazid, $\mathrm{KBrO} 3, \mathrm{HCl}$.

How it Works

\section{Iodimetry Test}

1. Prepare tools and materials.

2. Put $200 \mathrm{mg}$ of ascorbic acid into Erlenmeyer.

3. Add $50 \mathrm{ml}$ of $\mathrm{CO} 2$-free water and $10 \mathrm{ml}$ of $10 \%$ sulfuric acid.

4. One starch indicator pipette is added

5. Titrated with $\mathrm{I} 20.1 \mathrm{~N}$ until the end point of the titration is blue.

\section{Iodometric Test}

1. Prepared tools and materials

2. Add $250 \mathrm{mg}$ of $\mathrm{CuSO} 4.5 \mathrm{H} 2 \mathrm{O}$ into erlenmeyer.

3. Dissolved with $50 \mathrm{ml}$ of aquadest.

4. Added $10 \mathrm{ml} \mathrm{CH} 3 \mathrm{COOH}$ and 3 grams of $\mathrm{KI}$.

5. Titrated with $0.1 \mathrm{~N} \mathrm{Na} 2 \mathrm{~S} 2 \mathrm{O} 3$ (pale yellow color)

6. Added one starch indicator pipette.

7. Titrated with $0.1 \mathrm{~N} \mathrm{Na} 2 \mathrm{~S} 2 \mathrm{O} 3$.

\section{Bromatometric Test}

1. Prepare tools and materials to be used.

2. Add $150 \mathrm{mg}$ of izoniasid to erlenmeyer then dissolve it with aquadest.

3. Added $25 \mathrm{ml}$ of $0.1 \mathrm{~N} \mathrm{KBrO} 3$ and 2.5 grams of $\mathrm{KBr}$.

\section{Result and Discussion}

An oxidation reaction is the process of transferring electrons from an oxidizing or reducing agent. A reduction reaction is a reaction to capture an electron or a reaction where the oxidation number is decreased.

Table 1. Iodimetry Table

\begin{tabular}{|c|c|c|c|}
\hline \multirow{2}{*}{ Sample } & Weight Sample & Volume Titration & Change \\
\hline \multirow{2}{*}{ Ascorbat acid } & $0,102 \mathrm{~g}$ & $15,5 \mathrm{ml}$ & Clear to blue \\
\cline { 2 - 4 } & $0,101 \mathrm{~g}$ & $18,5 \mathrm{ml}$ & Clear to blue \\
\hline
\end{tabular}

Table 2. Iodometri Table 


\begin{tabular}{|c|c|c|c|}
\hline \multirow{2}{*}{ Sample } & Weight sample & Volume Titration & Change \\
\hline \multirow{2}{*}{$\mathrm{CuSO}_{4}$} & $0,102 \mathrm{~g}$ & $20 \mathrm{ml}$ & Blue to clear \\
\cline { 2 - 4 } & $0,101 \mathrm{~g}$ & $20 \mathrm{ml}$ & Blue to clear \\
\hline
\end{tabular}

Reducers commonly used for oxidation determination are potassium iodide, titanium (III) ions, iron (II) ions, and vanadium (II) ions. The method of titrating iodine as a pentiter is called iodimetry, while the idoin solution as the pentiter is idometry. In the iodimetric experiment, the way it works is that all the tools and materials are prepared. First, the burette was encapsulated on the stative, weighed 2 times for ascorbic acid, after weighing it, put it in Erlenmeyer then added CO2-free water, then homogenized. Added $5 \mathrm{ml}$ of $10 \%$ sulfuric acid, and added 1 pipette starch indicator then titrated with $\mathrm{I} 20.1 \mathrm{~N}$ and observed the end point of the titration. In the iodometric experiment, the tools and materials are prepared. First of all, the burette is attached to the stative. Weighed CuSO4 twice, then dissolved it in $50 \mathrm{ml}$ of water, added $10 \mathrm{ml}$ of $\mathrm{CH} 3 \mathrm{COOH}$, then added $3 \mathrm{~g}$ of KI. Cover with aluminum foil, and store in a dark place, add the starch indicator one pipette, then titrate with $\mathrm{Na} 2 \mathrm{~S} 2 \mathrm{O} 3$ and observe the end point of the titration.

\section{Conclusion}

From the experimental results above, it can be concluded that: In the idimetric experiment, in the first and second ascorbic acid samples, the end point of the titration is blue (clear - blue). In iodometric experiments, in the first and second CuSO4 samples, the end point of the titration is clear (blue - clear). For Laboratorium, It is better if the materials needed in the practicum are completed, so that the practicum can run well and the use of its time is effective.

\section{References}

Ammonium Sulphate by Novel Iodo-Potentiometric Method. Asian Journal of Chemistry, 22(7), 5209.

Degradation and removal methods for perfluoroalkyl and polyfluoroalkyl substances in water. Environmental Engineering Science, 33(9), 615-649

Ismail, M., Ali, S., \& Hussain, M. (2014). Quantitative determination of ascorbic acid in commercial fruit juices by redox titration. International Journal of Pharmaceutical Quality Assurance, 5(04), 22-25.

Merino, N., Qu, Y., Deeb, R. A., Hawley, E. L., Hoffmann, M. R., \& Mahendra, S. (2016).

Oromí-Farrús, M., Villorbina, G., Eras, J., Gatius, F., Torres, M., \& Canela, R. (2010). Determination of the iodine value of biodiesel using 1H NMR with 1, 4-dioxane as an internal standard. Fuel, 89(11), 3489-3492.

Suma, N., Jeevananda, T., \& Palanna, O. G. (2010). Determination of Cerium in Ceric

Yeboah-Awudzi, L. (2013). Stability Studies On Reconstituted Amoxycillin-Clavulanic Acid Oral Suspension by HPLC Development and Quantification (Doctoral dissertation)

Waples, D. W. (2013). Geochemistry in petroleum exploration. Springer Science \& Business Media. 